\title{
Media ecology and the future ecosystemic society
}

\author{
Juho Ruotsalainen ${ }^{1} \cdot$ Sirkka Heinonen $^{1}$
}

Received: 2 April 2015 / Accepted: 23 July 2015 /Published online: 8 August 2015

(C) The Author(s) 2015. This article is published with open access at Springerlink.com

\begin{abstract}
This article discusses a possible future, in which the network society is deepening to become an internet-based ecosystemic society. The study of the possible societal impacts of the 'media disruption' brought along by the internet has been somewhat neglected. The article thus examines the social consequences of the 'media disruption' from the perspective of the media ecology tradition, which takes media into account as 'living environments'. The article connects the media ecology tradition to the concept of the ecosystem, which has been primarily used in business economics discussions. In an ecosystemic economy, companies work in closer collaboration and share information more freely. One of the most central themes of the media ecology tradition is how different areas of society, such as private and public, work and leisure time and various institutions and organisations, begin to interlock as a consequence of the spread of electronic and digital media. The main argument of the article is that as the internet further penetrates all spheres of society, the metaphor of the ecosystem could serve as a metaphor for the entire society, not only for the economy. In this way it anticipates a possible future for the whole of society through changes in media. The article is part of the MEDEIA project (New roles and functions of media in the digital meanings society 2030) conducted at the Finland Futures Research Centre (FFRC), University of Turku.
\end{abstract}

Keywords Media $\cdot$ Journalism $\cdot$ Media ecology

Ecosystems $\cdot$ Economy $\cdot$ Digital age $\cdot$ Transformational futures

Juho Ruotsalainen

juho.ruotsalainen@utu.fi

Sirkka Heinonen

sirkka.heinonen@utu.fi

1 Finland Futures Research Centre (FFRC), University of Turku, Turku, Finland

\section{Introduction}

The changes in media and journalism that the internet has brought about are often discussed in terms of new business models and technologies. According to Steensen [64], research on online journalism has been dominated by a discourse of technological innovation. Lewis and Westlund [39] claim that during the past two decades, journalism studies have concentrated on the role of technology in news work. Additionally, the emphasis has been on the editorial side of news organisations, and broader, socio-technical considerations have been ignored [39]. The topic of social consequences of media has especially been neglected in futures research. Major futures research journals such as Futures, Foresight, European Journal of Futures Research, and Technological Forecasting \& Social Change do not return any results on the topic from the past 5 years with the search terms 'media' or 'journalism'.

New media culture and the social consequences of the "media revolution" have indeed received surprisingly little attention, considering the central role media and journalism as institutions have in society. New values and social functions of media and journalism may turn out as the most fundamental question concerning the new media environment. Siles and Boczkowski [63] for instance claim that "considerably more energy should be [aimed at] the empirical study of the social, cultural, and political implications of the newspaper crisis."

According to Schudson [60], the underdevelopment of the research on social consequences of the media disruption has partly resulted from the difficulties of measuring the social implications of newspapers in democratic life. The same applies to media and society in general: it is difficult to study empirically such broad and abstract phenomena as the interrelations between media and society. However, futures research with its exploratory, anticipatory, holistic and systems-oriented methodological and theoretical approaches 
$[4,17]$ could provide suitable means for the inquiry of the societal impacts of the media change.

The "digital age" in general is marked by dissolving of borders between various areas: between nation states, national markets, the local and the global, the public and the private, mass communication and interpersonal communication, professional and amateurs, production and consumption, and between different professions [65]. In journalism studies, the phenomenon is marked by the notion of "blurring boundaries" in media and journalism [41] and "media convergence" [30]. In broader terms these notions can be comprehended to refer to ecosystemic organisations, which offer the societal framework for this article (see Rethinking the network society as an ecosystemic society).

In futures studies, possible futures are often studied through technological innovations [5]. New technologies in general are seen as central factors in societal, and especially economic, changes $[13,16]$. Media technologies in turn can be seen as a major force behind cultural changes - and thus, according to Cornish [9] pointing to transformational futures. Indeed, the digitalisation of the media should be studied as a transformational change - but only when and if the values and operating logic of society change as well. The whole society must change, if we refer to changes as "radical", "disruptive", "transformational" or "revolutionary". It has to be kept in mind however, as we note in "Caveats - technological determinism and "built-in" power relations", that technologies do not determine social change, but are implemented and evolve in certain social, cultural, political and economic contexts.

Thus the most important question of the media discussion can turn out to be what the digitalisation of the media and journalism means for society as a whole: how is the change in the media and journalism related to the general change in society? The socio-cultural aspect-values, lifestyles, economics, politics, etc. - is a prerequisite for an in-depth understanding of the media revolution, since the critical turning points of the media have historically always occurred in association with broader societal change $[1,57]$.

In media research, such comprehensive social questions are studied especially within the media ecology research tradition. Media ecology sees media not only as means of communication, but more as social environments akin to any other social environment. Other research traditions, such as cultural studies [40] address the relationship between media and social change as well.

Perhaps the most notable tradition in this respect is the mediatization approach, which studies the consequences of mediated social relations, especially on politics. Mediatization theories share with media ecological approaches the fundamental notion of "communication as the basic practice of how people construct the social and cultural world" [33]. According to Clark [14], "Both [mediatization and media ecology] are concerned with how we might discuss the role that technologies of communication have played in shaping culture, and conversely, the ways in which we might take account of how cultural practices shape communication technologies."

"Strong forms" of mediatization theories are often criticized for being technologically deterministic $[14,33]$ as are media ecology theories. Social construction of technology (SCoT), in turn, studies the interaction between humans and technology and how human action shapes technology [8]. An example of SCoT oriented media research is social informatics, which "is the body of research that examines the design, uses, and consequences of information and communication technologies in ways that take into account their interaction with institutional and cultural contexts" [31].

Finally mentioned here is media effect research, which analyses short-term impacts of certain media content on the social world [59]. In opposition to media ecology and mediatization approaches, media effect research concentrates on media contents instead of media technologies. Accordingly, media effect research sees media contents as a source of societal change.

Outside the field of media studies, especially theories of the information society [70], post-industrialism [6], and the network society $[11,68]$ have investigated the relation between media and societal change. These concepts and theories are closely related to each other-they describe the same societal change in slightly different concepts and viewpoints. All of them depict society which is organised around information production and human capital. In all of them, producing ideas is the way to economic growth, and services replace material production as the mode of production. All of these three concepts point to postmodern culture which emphasises the construction of reality through language [69] and pluralistic, individualized culture with a plethora of interpretations, values and styles [70]. David Harvey [25] draws fundamental connections between postmodernism and neo-liberal economy. According to Harvey, the flexibility of postmodern culture supports the flexibility of neo-liberal economies. Harvey's observation is important as it highlights the central role economic relations have in all spheres of society.

In this article, we implement media ecology viewpoints in order to canvass the current relationship between change in the media and change in society. Whereas theories on the "information society" operate on an abstract level of information and networks, media ecology is better able to connect structural level with that of individuals. To avoid technological determinism often ascribed to the media ecology tradition, this article emphasises the interactive features of new media and social constructivist approaches towards media technologies (see Caveats - technological determinism and "built-in" power relations).

Compared to other research traditions on media, information technologies, and social change, media ecology is especially topical as it sees media as social environments, 
analogous to physical social environments. As people are constantly connected to interactive social media platforms through mobile devices, media environments are perhaps becoming as central social spaces as much as physical spaces are. According to Meeker [44], the daily hours people spend with digital media in the United States have more than doubled between 2008 and 2014 from 2.7 to $5.6 \mathrm{~h}$; mobile hours have increased almost tenfold from 0.3 to $2.8 \mathrm{~h}$. The situation is naturally different in developing countries, but in 2014 there were already 2.8 billion internet users globally. Between 2012 and 2014 internet user growth was on average $10 \%$ per year, but in India the annual growth rate was $33 \%$.

To observe change in the structural constitution of society, we utilise the concept of the ecosystem, which is mainly used as a model and theory for economic organisation. An economic ecosystem refers to an 'informal' business entity based on collaboration and information-sharing and crossing the borders of the companies' fields of industry. The internet offers basic infrastructure for the economic ecosystem as it aids in informationsharing and communication across different borders.

The main argument of this article is that as more and more of social interaction takes place on the internet, society as a whole can begin to develop in accordance with the ecosystemic organisation model. An "ecosystemic society" is one in which the lines between different spheres of life - such as the public and the private, or work and leisure - begin to blur.

We link the metaphor of the ecosystem to the media ecology tradition. In this respect, Marshall McLuhan's concept of the global village and Harold Innis's concept of the oral tradition are especially usable. McLuhan's global village refers to a society defined by electronic media, where social relations begin to resemble again those of pre-industrial communities. As in these communities, in the global village different spheres of life become once again intertwined [42]. One of Innis's [28] central ideas was that as written language inescapably abridges and simplifies human thought, the spread of the written word impoverishes culture. Furthermore, as written text is not an interactive medium, it fosters differentiation and separation at the cost of cooperation. Oral "media", on the other hand, enable fuller and more holistic expression and thought compared to writing. This article claims that the hypertext and interactive nature of the web steers written expression toward that of oral tradition, and thus promotes a revisited "oral culture". As in McLuhan's global village, in Innis's oral culture institutions and areas of life are not as separate from each other as they have been since the industrial revolution.

\section{From media technology to media ecology}

Media is still often defined as a means of communication [61]. Joshua Meyrowitz [46] claims that the most common metaphor for media is that of a vessel or a conduit. This metaphor sees media as a neutral means for information delivery, and thus focuses analysis on media contents instead of media itself. The shortcoming of this approach is that neutral, technology-orientated definitions are insufficient for examining the social impact and relationships of the media.

According to Meyrowitz [46], the other two often used metaphors for media are media-as-language, which sees different media having a unique range of expressive potential, and medium-as-environment, which sees different media having characteristics that make them physically, psychologically and sociologically different from other media. On micro level, the environment metaphor focuses attention on how media influence particular situations and interactions. On macro level, the metaphor prompts to investigate how different media facilitate interactions and social structures in general [46].

In the 1950s and 1960s, the medium-as-environment metaphor developed as a distinct research agenda. Media research was approached through the concept of media ecology, particularly due to the influence of the media theorists Harold A. Innis, Marshall McLuhan and Neil Postman. As the name implies, media ecology broadens the definition of media from a means of communication to encompass an entire living environment. Innis, McLuhan, Postman and other media ecologists were interested in how different media technologies offer a social environment for society and the whole human existence - and not so much in the contents or "messages" these media delivered. As the internet is becoming increasingly ubiquitous, the perspective of media as living and social environment is more topical than ever.

The media ecology tradition perceives media as a structure in which society and culture evolve - as an environment where people act and live their lives, and through which reality is perceived. Culture and social and societal relationships are created through human communication. This is why the media technology of each era-i.e., the means through which people communicate - significantly sculpts culture, ways of thinking, values, social and power relationships; in short, human existence $[26,29,50]$. To be more precise, it is not the technology that sculpts culture but the communication which takes place in certain media.

Media ecology observations gained momentum from the 1960 s to the 1980s, when electronic media grew more and more commonplace and filled everyday life with information. However, according to Paul Levinson [38], the media ecology tradition has become truly useable only with the emergence of the internet. It is only the internet that has managed to create its own alternative media environment comparable to physical reality - a symbolic environment filled with abstract experience [54].

According to Levinson [38], this is due to three reasons in particular. Firstly, the internet brings together all previous media-speech, written and printed text and electronic audiovisual media. The internet is thus richer and more versatile 
as an environment compared to previous media. The internet enables more versatile technology-mediated communication and is able to encompass a larger proportion of human experience. Secondly, the internet is a fundamentally interactive medium where the sender and the recipient are not clearly distinguishable. Because of this interactivity, people can act in a very similar manner on the internet to the way they would in physical reality. Thirdly, due to its associative, hypertextlike structure, the internet resembles human thought processes and the original medium - speech - and is thereby almost intuitively incorporated into all human actions [38].

In addition to the characteristics of the internet described by Levinson, a fourth could be added. Together with the increasing computing and storage capacity of microchips, the internet has remarkably decreased the costs of producing, distributing and processing information. As a result, information and cultural contents have blended in everywhere and have become a kind of shared resource. Affordable information can be seen as the primary reason for the media saturation of our contemporary reality. Mobile devices in particular have brought along the constant presence of media content and environments. The development is further deepened along the so-called 'Internet of Things', where knowledge and information technology is embedded into artefacts and everywhere in the built environment. Cutting edge virtual reality and augmented reality technologies, such as Facebook's Oculus Rift and Microsoft's HoloLens claim to blend the virtual and the physical as almost inseparable from each other [53].

\section{The media ecology of the internet}

As the internet is a "multimedia", it merges together the features of the media preceding it. The internet combines the subjectivity, non-linearity, interactivity and free association of speech $[29,54]$, the analysis, linearity and objectivity of written and printed text $[43,55]$, and the experience-orientedness and the 'total view' of audio-visual media $[42,55]$.

This mix has its distinct socio-cultural and cognitive tendencies, and it may steer towards a "holistic" society, which is described as an ecosystemic society in the next chapter. On the internet, all communication takes place through the same medium and in the same 'environment'. Castells [11] calls this feature of the internet symbolic isomorphism: on the internet, different methods of expression and cultural expressions are morphed into each other. According to Castells, the consequential mixing of worlds of experience promotes the mixing of institutions and areas of life [11]. For example, when employees use social media during their work day, leisure time is mixed with work time and vice versa.

Even though the internet connects the previous forms of media with each other, it is still a text-orientated mediumalbeit visual expressions are gaining more and more momentum, as exemplified by the rise of photo sharing social media such as Instagram and the increasing use of pictographs such as emojis. Furthermore, the internet does not preserve text in its old form. Symbolic isomorphism moulds the nature of text. On the internet, text resembles speech in many respects [38]. Unlike written texts or manuscripts, the written text of the internet enables immediate interaction, similarly to speech. Writings presented on the internet are often colloquial, unlike printed text. The hypertext structure of the internet breaks the linearity of written language: hyperlinks embedded into the text give the text an associative nature similar to human thought and its most direct expression, speech. In contrast to traditional written text, hypertext does not reveal a single, restricted perspective on reality, but installs itself as a part of the broader 'total view'. Hypertext is a shared form of expression, in which a singular author with a singular voice is questioned [18].

It can also be claimed that since the associative nature of hypertexts resembles thinking, the contents of the internet are better merged as an organic part of the users' consciousness, as compared to earlier media. As stated above, speech is the most personal of all media: as a person speaks, they directly express their subjective ideas and emotions. Since text on the internet is often speech-like, the user becomes the central content of the internet [38]. When a large part of the internet's contents are produced by users rather than institutions, the contents are primarily expressions of individual personalities. However, due to the hypertext, individual personalities are enmeshed in the texts on the internet. Indeed, the internet is the first medium to be simultaneously private and public: private communication has become publishing and publishing has become private communication [62]. The enmeshing of the private and the public is a central feature of the ecosystems as well, as depicted in "Rethinking the network society as an ecosystemic society".

The simultaneous private and public nature facilitates creating communities around shared interests, values and tastes. On the internet, the formation of communities and social relationships is not hindered by geography, physical contacts, social status and the like. Instead, individuals can form relationships with basically whomever they want [12, 56]. Levinson's [38] idea of the "user as the content on the internet" can be extended to the thought that in the future, the contents of the internet will not be primarily comprised of individual users, but of user communities. User communities and other ad hoc organisations may provide the main organisational principle for the ecosystemic society as well.

User communities help to make culture and political discussion organically vivid and democratic. Speech and speechlike text play a central role here as well. Harold Innis [28, 29] stresses the importance of speech for the organisation of societies. One of Innis's central ideas is that the oral tradition prevents the emergence of information monopolies. Speechmediated culture is preserved by all individuals within a 
culture. Since the culture thus relies on the memory and 'persona' of the community and its members, the oral tradition is lively, rich, adaptive and flexible. In ecosystemic production and organisations, information monopolies are hard to maintain, as information flows freely between individuals and organisations.

The oral tradition resembles McLuhan's [37, 42] concept of the global village. The global village is often narrowly understood as a global world where distance has lost its importance. For McLuhan, however, the central notion is that because of the impact of electronic communication, the whole of social reality has begun to resemble the social reality of a village. In a village, spheres of life and society are not separated and specialized as they are in an industrialised society, but form a unified, organic whole. The global village is a world of global communication, but is first and foremost a form of society where the distinctions of modern time, such as private vs. public, work vs. leisure time, and expertise according to profession, have faded.

It is crucial to note that McLuhan wrote his ideas during the era of television. Television did not enable the emergence of a global village, since it left media consumers in the role of passive spectators [38]. Now, one could claim that by rendering the dominant form of media contents as speech-like and interactive writing, the internet supports the birth of a community-like social organisation - or, in McLuhan's words, a global village. This would also revive the oral tradition longed for by Innis. The free information flows of the global communication network would create an organic whole where everything is again connected with everything else. Power would be transferred from bureaucratic and representative organisations to individuals and their communities. This possible development can be described as an ecosystemic society.

\section{Caveats-technological determinism and "built-in" power relations}

Before we continue to outline the ecosystemic society and its relations to the internet, an outlook on the criticism towards media ecology is needed for a balanced view. The most common critique on the media ecology tradition is that of technological determinism [40]. The critics claim that media ecologists draw an overly simplified picture of a technologically determined social change.

Technological determinism, or its "hard" approach, ascribes technology with omnipotence in shaping society [51]. Technologies are seen as independent forces shaping society regardless of social, cultural and power-related factors. Raymond Williams [71], a well-known critic of media ecology and McLuhan in particular, notes that technological determinism reduces all other causes of social change - economic, social, cultural and political — as mere effects of certain technologies which have no independent role in affecting society. Instead, according to Williams, technology should be seen as socially created and recreated — arising from human interests, intention, and agency.

Indeed, media ecology approaches can be criticized for grandness - as if all social change and the human condition could be reduced to media technologies [14]. Still, their logics are often more nuanced than what their critics claim. Innis saw each media created by the powerful in society to serve their interests-i.e., as socially constructed [15]. McLuhan claimed media as "extensions of man", and thus in a cybernetic, interactive relationship with the users. Clark [14] states that "Postman seemed interested in distinguishing the media ecological approach from technological determinism. [...] He described culture as something that is constituted in the interaction between media and human beings."

Despite these nuances, both Innis and McLuhan are "hard" determinists because they saw media having direct effects on the psyche and mental structures. However, later media ecologists bend toward the "soft" version of technological determinism, which sees technologies as facilitators of change instead of determinants, and constantly moulded by their users [51]. Donna Flayhan [20] notes that prominent post-Innis/McLuhan media ecologists James Carey and Joshua Meyrowitz are social constructivists rather than determinists. Meyrowitz [45], for instance, grounds his approaches to the social psychology of Ervin Goffman, and criticizes McLuhan of his views about media altering the "neural balance" of their users.

To combine the objective and subjective aspects of media, media should be seen as societal institutions [32]. According to Giddens [23], institutions are objective structures in the sense that they lay out the rules for social action, and subjective in the sense that institutions can only exist in the minds of the citizens and are realized through their actions. When enough citizens start to act differently, institutions change.

As institutions, media are in constant interaction with users in certain socio-economic contexts. Thus it is important to conceptualize media technologies from a social constructivist viewpoint - to see media technologies defined at least as much by their use and social definitions as their technological and "objective" features. At the same time it has to be kept in mind that media have different technological features, which to some extent determine how they can be used - media structure social action, but do not determine it.

The second precaution of this article is about power relations embedded in new digital technologies. This article draws an ideal-type outlook on digital media and its societal implications. That is, what kinds of social and societal relations do the technological features of the internet enable. The focus is on possible societal implications of the internet. The de facto appliances, uses and consequences of the internet are out of the focus of this article. We depict a possible future, in which ICTs are used to erode traditional societal and cultural 
boundaries. It is a task of further research to assess more nuanced social and ethical implications of the transition.

Economy is perhaps the most important societal force, and creates the preconditions for new media as well [22]. In its current form, especially in the age of social media, the internet is dominated by large multinational corporations such as Facebook and Google. The services through which people use the internet thus ultimately serve the commercial interests of the service providers. For instance, the Facebook user interface is designed to gather users' personal information to better target advertisements. This promotes certain kinds of communication and self-expression at the expense of others. This is a clear example where economic relations at least to some extent determine media use and social behaviour. It reflects Castells' [12] notion that power struggles are increasingly about identity and symbols, as can be seen in the ways social media corporations try to conduit and regulate people's self-expression. Power struggles take place between local actors - such as citizen movements - and multi-national companies, instead of within institutions of the nation state [ibid].

Furthermore, in the prevailing cyber-libertarian discourse of the internet [58] it is often forgotten that although the internet liberates communication by letting everyone be a publisher it also opens up new tools of control and surveillance for states and companies. As states and companies have more resources than citizens, they can often use new technologies in more efficient ways to promote their interests than citizens [34, 49].

The internet is a "libertarian" media in the sense that it is in large part out of control of the democratic institutions of the nation state. This emphasizes the role of individuals. According to Scott Lash [35], in the future, the most important division will be between "reflexivity winners" and "reflexivity losers", and social statuses would be determined by one's position within communication structures instead of production structures. Lash [36] describes the transition as an internalization of power. As citizens self-organize and self-express using algorithm-based services, algorithms and their embedded corporate interests become part of citizens' identities. When digital services "personalize" media contents through algorithms, digitalized media becomes a "technological unconsciousness" which affects the symbols through which we think and make decisions [3].

Finally, it can be argued that the whole technological structure of the internet is determined by power relations - by certain ideas about the "ideal" social structure and human relations. Media - as technologies in general - are never valuefree. As mentioned earlier, Neil Postman [54] states that media technologies are "a set of ideas or ideologies". Fred Turner [66] argues that the counter-culture ethos of the 1960's was a crucial factor in the creation of the early internet in the 1960's and 1970's. According to Turner, the early innovators of the internet and the personal computer were motivated by the idea of a communication technology which couldn't be controlled from any centre, and which would grant individuals unforeseen communicative freedom. In the 1990's this idea was increasingly used in the service of neo-liberal politics [66] internet is a crucial enabler of the globalized economy. Thus, it can be claimed that the nature of the future internet is defined by the power struggles of how the "freedom" embedded in the technological structure of the internet is defined and practised-that is, the social construction of the internet within certain socio-economic contexts.

\section{Rethinking the network society as an ecosystemic society}

According to Joshua Meyrowitz [33], 'electronic media' (radio, television, computers, etc.) promote a change in society by connecting previously separate social spaces and spheres with each other. Before electronic media, social spaces were tied to physical spaces. Physical barriers - walls, doors, windows etc. - controlled information flows and efficiently separated social spaces from each other. When electronic media made access to information less dependent on face-to-face communication, the connection between social spaces or roles and a specific physical space became slacker [45].

According to Meyrowitz [45], as a result of this development, social spaces and spheres begin to merge and affect each other. For instance, in the 1970s and 1980s politicians began to perform in a more informal manner, as the values of the private sphere transferred into the public sphere due to the spread of television. Now, as the internet frees information flows from physicality even further, it is reasonable to anticipate that institutions, organisations and spheres of life will begin to merge together more radically than what we have seen to date.

Meyrowitz's media ecology perspective helps to complement the flaws of the so-called network society theory. According to the theory, along with the rise of information and communication technologies, hierarchical bureaucracies are being replaced with more equal and interactive networks. Network society theories often include an idea of an 'ideal' network society, in which the network metaphor encompasses the entire society and where all sections of society are closely interlinked [12, 67, 68].

In practice, however, the concept of a network society has established itself to refer merely to quite detached organisations that have organised into networks internally and within their field. For example Manuel Castells mainly describes in his famous information age trilogy the network-formation processes within economics and politics [12]. In practice, network society theories for the most part speak of a society of separate networks rather than a unified network society. 
Network society analyses thus reach halfway only. This can be due to the fact that network society discussions were at their most heated from the mid-1990s to the early 2000s, when the internet was only just beginning to become common. It can be claimed that only the internet is able to create an 'ideal' network society, where all actors of society are networked across sector borders. Indeed, the most important social aspect of the internet might be that it is able to connect existing networks with each other. After all, the internet is, in itself, a network of networks. According to van Dijk [68], on the internet, social, economic and media networks are integrated with each other.

This perspective takes Meyrowitz's idea of an 'electronic media-based' society a step further, to a society where social spaces and institutions can no longer be clearly distinguished from one another. All actors would be part of the same connective tissue or communication network. Borders between different organisations, institutions and, in a broader sense, the private and the public, would be dissolved as information flows more freely between them. At the same time, the communication network would be fused as a part of the individual's thought processes as a result of its associative and speech-like nature. Following this, the borders between the individual and their networks could also dissolve.

This development could even set under question the whole modern notion of separate, self-contained individuals, as Katherine Hayles has suggested [26]. These changes can already be seen in the "millennial" generation, born between 1980 and 2000. Having used computers and the internet all their lives, millennials see themselves equally as individuals and as parts of multitudes of collectives [10]: "When teens create profiles online, they're both individuals and part of a collective. Their self-representation is constructed through what they explicitly provide, through what their friends share, and as a product of how other people respond to them."

The concept of the ecosystem, which in recent years has become common in business economics discussions [27], is very similar to the previously described media ecology idea of a thoroughly networked society with fused institutions. The ecosystem is originally a concept derived from biology, referring to an entity formed by living organisms and lifeless objects in a specific environment. In the 1990s, the technology and computer industry adopted the metaphor of the ecosystem to refer to business organisations $[47,48]$.

A business ecosystem consists of all of the actors within one production industry: individuals, organisations, companies, and clients. The ecosystem is not really based on competition but rather on collaboration, on the 'symbiotic' relationships between actors. The actors of an ecosystem openly share information, collaborate and strive to reach shared goals. Each actor specialises in their own 'ecological niche' from which they gain their profits. Just as the internet might contest the notion of individuality, the ecosystem questions corporations - or organisations and institutions in generalas separate units [47, 48, 52].

An ecosystemic economy is based on the information and communication technologies that have dramatically decreased the costs of producing, processing and distributing information. Companies benefit from a more open distribution of information, since they no longer have to rely on internal immaterial capital only. Information-sharing is thus thought to promote the birth of innovation, as companies have access to vastly more information [7]. Since the consequences of the decrease in information costs are not limited to the economy and production, economic ecosystems can be regarded as weak signals of a development where the whole of society is organised as an ecosystem. In an ecosystemic society, the societal changes discussed within the media ecology tradition no longer depend solely on the media, but are supported by the economy as well.

In an ecosystemic society, not only economic actors but all actors in society would begin to network and collaborate in a very open manner. This would not be caused by the internet per se, but would rather reflect the individualistic, antiauthority and grassroots values of the late- or post-modern culture. Society would be based on open information flows, open source principles familiar from the software industry and ad hoc organisations. Ubiquitous information networks would connect diverse thoughts, cultures, institutions, organisations and individuals. Everything would be a part of the same whole, and the border between, for example, work and leisure and private and public would become increasingly ambiguous or dissolve completely [24] —as in McLuhan's global village view.

Companies would work in closer collaboration not only with other companies and businesses, but also with citizens and consumers. Large organisations and traditional institutions would lose their foothold, as citizens and other small actors would organise and act with each other. Within the culture, the horizontal 'living world' of people would grow at the cost of the vertical and hierarchical 'system world' of organisations. At the same time, in order to be successful, organisations and traditional institutions would have to adapt their activities to the values and expectations of the living world. The private life sphere would merge with the economic sphere, and all human know-how, skills, emotions, thoughts, hobbies, etc., could be utilised in value-creation.

A culture that connects areas with each other would not, however, be homogenous, but, thanks to the interactive nature of the internet, it would constantly live and change, in accordance with Innis's oral tradition. Media contents would replace traditional sources of significance, meaning and identity, such as nation states, waged work or material consumption. Culture and shared meanings would constantly be (re)defined, (re)created and (re)constructed in the information flows of the internet. 
The development of an ecosystemic society would, of course, not occur without conflicts, but would bring about new kinds of problem. A society organised at grassrootslevel is individual-orientated, which might deepen social inequalities. An ecosystemic society is based on communication, which would mean that cultural capital and interactive skills would be emphasised. Cultural and social capital would separate citizens into unequal positions even more than today. Hierarchies of power would gain new forms.

When life management is closely linked with symbolic management, every citizen would have to build the significance and meaning of their own lives on media contents. The more cultural and social capital they had, the better the chance of success in this matter. Similarly, those individuals with the best resources for communicating and producing media content would have the largest power in defining the shared reality and its values.

An ecosystemic society is also radically open, at least on an ideal-type level. In a world of open information, the traditional conception of privacy might crumble and data collection might open new opportunities for manipulation and exercising power. The exercise of power might also become more hard to distinguish, as data resources provided companies with more direct access to people's intimate life spheres. Radical openness can create a kind of cyber panopticon [21], where the awareness of the possibility of constant surveillance might begin to 'normalise' the way in which people think and behave.

However, the concept of the ecosystem is problematic primarily because while it seemingly describes society as a whole, it first and foremost still concentrates on the sphere of economics and business. In the present ecosystem discourse, economy and competitiveness hold hegemony, and the objective of 'organic networks' is above all to serve economic productivity. If work is transformed into something resembling leisure time, it might mean the emergence of 'capitalism to the core', where the whole of human life is subjected to economic value-creation. In other words, the criticism David Harvey [25] has presented on the parallels between information technologies and neo-liberal economy applies to ecosystemic organisations as well. The ecosystem discourse gives a promise of emancipation, but it might also close people within the sphere of value-creation and the collective use of power more strongly than ever.

\section{Conclusion: postmodernism succeeded by the post-internet?}

In this article we have described the basic features of the media ecology of the internet and drawn parallels between internet's media ecology and the ecosystemic society. The internet blends written text, speech and audiovisual media.
Thus, on the internet different cultural expressions and spheres are morphed into each other. Furthermore, interactive, colloquial and non-linear hypertext does not reveal a single, restricted perspective on reality, but offers a broader 'total view'.

These features of the internet have close resemblance with Marshall McLuhan's concept of the "Global Village" and Harold A. Innis "oral tradition". In the "global village" [42] different spheres of life are enmeshed together, and especially the private and the public. It is a world where "everything is connected to everything else". Innis [28] describes orality as a medium which can express human thought more comprehensively than writing. Analogous with the hypertext, speech is also an interactive, colloquial and non-linear medium.

The blurring of boundaries between different spheres of life is a common thread in the media ecology tradition, as described by Meyrowitz [45]. In journalism studies, the same phenomenon is marked by the notion of "blurring boundaries" of journalism [41] and by the "media convergence" [30]. In business and management literature an analogous phenomenon is understood as the business ecosystems. In business ecosystems separate firms begin to merge (informally) into each other and into the rest of society, as a consequence of open information exchange and cooperation. Thus, this article has argued that the media ecology of the internet and the ecosystemic economy point toward a future in which the whole of society organizes itself around ecosystemic principles. This kind of society forms an organic whole, where different actors and spheres of life are intertwined in novel ways through the information flows of the digital media.

Which new concept of contemporary analysis could encapsulate the spirit of the "ecosystemic era"? If "postmodernism" described the culture of the network society, then postinternet, for its part, could be the successor of postmodernism as a concept of contemporary analysis [19]. Post-internet does not refer to an era after the internet, but, on the contrary, to the era where the internet has become a norm. The concept is in this sense comparable to the concept of postmodernism. According to one interpretation, postmodernism did not refer to a time after modernism, but to a mature modernism: an era where 'modern' and its values had established their status and become a part of everyday life; where modern had reached its potential [2].

Similarly, post-internet refers to a society where the internet is present everywhere and which is partly defined by the internet and its uses and values. For the first time a specific communication technology would define the whole of society from its economy to its culture. The concept would be justified in the sense that - as we have argued in this article - the internet is an environment that is more comparable to physical reality, in contrast to earlier forms of media.

While the postmodern society was based on individualism, the basic unit in the post-internet society could be 'user communities' derived from the internet. Indeed, according to van 
Dijk [68], the basic unit of the 'network society' of the future will be a networked individual. A networked individual is already now the basic actor in various online user communities, from community services such as Facebook to Wikipedia and blog communities. If the ecosystemic model establishes itself as the organisational form of the society, such individualorientated communities might spread from the internet to the whole of society.

In such a world, organisations could develop into platforms that facilitate the activities of individuals. People would form more or less personal relationships, which would foster various productive activities with the help of the resources of organisation platforms. In post-internet-era society, individual actors, citizens and their collectives would establish their status as exercisers of power in addition to large organisations.

However, companies, governmental organisations and other established institutions would simultaneously be a part of the super-network that formed society. If the activities of user communities materialised within the sphere of these organisations, they could gain an even stronger status in the lives of individuals. We therefore need more research in order to anticipate how the ecosystemic society and its values, power structures and modes of operation could develop in practice. Will the internet free up individuals and their communities to become autonomous, independent actors? Or will established institutions close in a larger part of human activity within their spheres, to be reigned over according to their objectives and operating logic?

Open Access This article is distributed under the terms of the Creative Commons Attribution 4.0 International License (http:// creativecommons.org/licenses/by/4.0/), which permits unrestricted use, distribution, and reproduction in any medium, provided you give appropriate credit to the original author(s) and the source, provide a link to the Creative Commons license, and indicate if changes were made.

\section{References}

1. Anderson CW, Bell E, Shirky C (2012) Post-industrial journalism: adapting to the present. Columbia Journalism School

2. Beck U, Giddens A, Lash S (1994) Reflexive modernization. Politics, tradition and aesthetics in the modern social order. Stanford University Press

3. Beer D (2009) Power through the algorithm? Participatory web cultures and the technological unconscious. New Media Soc 11:985

4. Bell D (1974) The coming of post-industrial society. Harper Colophon Books, New York

5. Bell W (1997) Foundations of futures studies. Volume 1, history, purposes, and knowledge. New Brunswick. $365 \mathrm{p}$

6. Bell D (2009) The coming of post-industrial society. Harper Colophon Books, New York

7. Benkler Y (2002) Coase's penguin, or linux and the nature of the firm. http://www.yale.edu/yalelj/112/BenklerWEB.pdf

8. Bijker WE (1995) Of bicycles, bakelites, and bulbs: toward a theory of sociotechnical change. MIT Press, Massachusetts
9. Blaagaard BB (2013) Shifting boundaries: objectivity, citizen journalism and tomorrow's journalists. Journalism 14(8):1076-1090

10. Boyd D (2014) It's complicated. The social lives of networked teens. Yale University Press, New Haven

11. Castells M (1996) The rise of the network society. The information age, economy, society and culture vol. I. Blackwell, Oxford

12. Castells M (1997) The power of identity. The information age: economy, society and culture vol. II. Blackwell, Oxford

13. Chan L, Daim T (2012) Exploring the impact of technology foresight studies on innovation: case of BRIC countries. Futures 44(2012):618-630

14. Clark LS (2009) Theories: mediatization and media ecology. In: Lundby K (ed) Mediatization. Concept, changes, consequences. Peter Lang Publishing, New York

15. Comor E (2001) Harold Innis and the 'bias of communication'. Inf Commun Soc 4(2):274-294

16. Cornish E (2004) Futuring. The exploration of the future. World Future Society, Bethesda

17. de Jouvenel H (2004) An invitation to foresight. Futuribles, Paris

18. Doherty S (2014) Hypertext and journalism. Digit Journal 2(2): 124-139

19. Droitcour B (2014) Why I hate post-internet art. http://culturetwo. wordpress.com/2014/03/31/why-i-hate-post-internet-art/. Read 10. 6.2014

20. Flayhan DP (2001) Cultural studies and media ecology: Meyrowitz's medium theory and Carey's cultural studies. N J J Commun 9(1):21-44

21. Foucault M (1995) Discipline and punish: the birth of the prison. Vintage Books, New York

22. Garnham N (2000) Emancipation, the media and modernity. Oxford University Press, Oxford

23. Giddens A (1984) The constitution of society: outline of the theory of structuration. Polity Press, Cambridge

24. Glenn J (2012) Futures for work, economy, growth and ubiquitous technology. Interview of Jerome Glenn by Sirkka Heinonen, Turku 6.6.2012. https://www.youtube.com/watch? $\mathrm{v}=\mathrm{ttLE9QoE7g8}$

25. Harvey D (1989) The condition of postmodernity. An enquiry into the origins of cultural change. Blackwell, Oxford

26. Hayles K (1999) How we became posthuman: virtual bodies in cybernetics, literature and informatics. The University of Chicago Press, Chicago

27. Hwang VW (2014) The next big business buzzword: ecosystem? Forbes, http://www.forbes.com/sites/victorhwang/2014/04/16/thenext-big-business-buzzword-ecosystem/

28. Innis HA (2007) Empire and communications. Dundurn Press Limited, Toronto, Kindle Edition

29. Innis HA (2008) The bias of communication. University of Toronto Press, Toronto, Kindle Edition

30. Jenkins H (2006) Convergence culture. Where old and new media collide. New York University Press, New York

31. Kling R (2000) Learning about information technologies and social change : the contribution of social informatics. Inf Soc Int J 16(3): 217-232

32. Klinger U, Svensson J (2014) The emergence of network media logic in political communication: a theoretical approach. Online article. doi:10.1177/1461444814522952

33. Krotz F (2009) Mediatization: a concept with which to grasp media and societal change. In: Lundby K (ed) Mediatization. Concept, changes, consequences. Peter Lang Publishing, New York

34. Lanier J (2010) You are not a gadget. Vintage Press, New York

35. Lash S (1994) Reflexivity and its doubles. Structure, aesthetics, community. In: Beck U, Giddens A, Lash S (eds) Reflexive modernity. Politics, tradition and aesthetics in the modern social order. Polity Press, Cambridge, pp 110-173

36. Lash S (2007) Power after hegemony. Cultural studies in mutation? Theory Cult Soc 24:55 
37. Leikola A (1984) Foreword. In: McLuhan M (ed) Ihmisen uudet ulottuvuudet. WSOY, Juva, In Finnish

38. Levinson P (2001) Digital McLuhan. A guide to the information millennium. Routledge, New York

39. Lewis SC, Westlund O (2015) Actors, actants, audiences, and activities in cross-media news work. Digit Journal 3(1):19-37

40. Lister M, Dovey J, Giddings S, Grant I, Kelly K (2003) New media: a critical introduction. Routledge, London

41. Loosen W (2015) The notion of the "blurring boundaries". Digit Journal 3(1):68-84

42. McLuhan M (1994) Understanding media. The extensions of man. The MIT Press, Massachusetts

43. McLuhan M (2011) The Gutenberg galaxy. University of Toronto Press, Toronto

44. Meeker M (2015) Internet trends 2015. http://www.kpcb.com/ internet-trends

45. Meyrowitz J (1985) No sense of place. The impact of electronic media on social behavior. Oxford University Press, Oxford

46. Meyrowitz J (1999) Understandings of media. Research library; 56, 1. http://www.mao52115.tcu.edu.tw/handout/media/resourse/01 Meyrowitz Understandings $\% 20$ of $\% 20$ media.pdf

47. Mitleton-Kelly E (2003) Complex systems and evolutionary perspectives on organisations: the application of complexity theory to organisations. http://citeseerx.ist.psu.edu/viewdoc/download?doi= 10.1.1.98.3514\&rep=rep1\&type=pdf. Retrieved 1.4.2015

48. Moore JF (2012) The death of competition: leadership and strategy in the age of business ecosystems. HarperCollins, New York

49. Morozov E (2013) To save everything, click here. The folly of technological solutionism. Public Affairs, New York

50. Ong WJ (2012) Interfaces of the word. Studies in the evolution of consciousness and culture. Cornell University Press, London, Kindle Edition

51. Paragas FC, Lin T (2014) Organizing and reframing technological determinism. New Media Soc. doi:10.1177/1461444814562156, Published online

52. Peltoniemi M, Vuori E (2004) Business ecosystem as the new approach to complex adaptive business environments. In: Proceedings of eBusiness research forum. pp 267-281

53. Pescovitz D (2014) Just say know: a cyberdelic history of the future. Presentation held at the Lift Conference, Geneva 7.2.2014. https:// www.youtube.com/watch? $\mathrm{v}=4 \mathrm{~s} \_8 \mathrm{XnMmChw}$. Watched 28.4.2014
54. Postman N (1982) The disappearance of childhood. Random House, New York

55. Postman N (1984) Amusing ourselves to death: public discourse in the age of show business. Viking Penguin Inc, New York

56. Rheingold H (2000) The Virtual community. Homesteading on the electronic frontier. The MIT Press, Massachusetts

57. Rifkin J (2011) The third industrial revolution. Palgrave Macmillan, New York

58. Ritzer G, Jurgenson N (2010) Production, consumption, prosumption. The nature of capitalism in the age of the digital 'prosumer'. J Consum Cult 10(1):13-36

59. Rosengren KE (ed) (1994) Media effects and beyond: culture, socialization, and lifestyles. Routledge, London

60. Schudson M (2010) News in crisis in the United States: panic - and beyond. In: Levy DAL, Nielsen RK (eds) The changing business of journalism and its implications for democracy. Reuters Institute for the Study of Journalism, Oxford, pp 95-106

61. Seppänen J, Väliverronen E (2013) Mediayhteiskunta. Vastapaino, Tampere, In Finnish

62. Shirky C (2008) Here comes everybody: the power of organizing without organizations. Penguin, New York

63. Siles I, Boczkowski PJ (2012) Making sense of the newspaper crisis: a critical assessment of existing research and an agenda for future work. New Media Soc 14(8):1375-1394

64. Steensen S (2011) Online journalism and the promises of new technology. A critical review and look ahead. Journal Stud 12(3):311327

65. Steensen S, Ahva L (2015) Theories of journalism in the digital age: an exploration and introduction. Journal Pract 9(1):1-18

66. Turner F (2006) From counterculture to cyberculture. Stewart brand, the whole earth network, and the rise of digital utopianism. The University of Chicago Press, Chicago

67. van Dijk J (1991) The network society: social aspects of new media. De netwerkmaastchappij Bohn Staflen Van Loghum, Houten

68. van Dijk J (2012) The network society, 3rd edn. Sage Publications, London

69. Vattimo G (1992) The transparent society. Polity, Cambridge

70. Webster F (1995) Theories of the information society. Routledge, New York

71. Williams R (1974) Television: technology and cultural form. Fontana, London 